\title{
Effects of Fungicides for Non Target Fungi
}

\section{Alternaria cassiae}

\author{
Silvia Patricia Carraschi ${ }^{1 *}$, Claudinei da Cruz $^{2}$, Aritana Gil Basile ${ }^{3}$, Robinson Antonio \\ Pitelli ${ }^{3}$
}

\author{
${ }^{1}$ Universidade de Araraquara. Av. Maria Antonia Camargo de Oliveira, 170 - Vila Suconasa, Araraquara - SP, 14807-120, \\ Brasil. \\ ${ }^{2}$ Centro Universitário da Fundação Educacional de Barretos (Unifeb), Barretos (SP). \\ ${ }^{3}$ Núcleo de Estudos e Pesquisas Ambientais em Matologia (NEPEAM) da UNESP, Campus Jaboticabal (SP).
}

\begin{abstract}
The fungicides are used to control of pathogenic fungi in several tilth but they can affect negatively the microorganisms diversity of soil. The aim of this research was to evaluate the toxicity and environmental risk of tebuconazoles: captan, tebuconazole and the mixture chlorothalonil + propamocarb hidrochloride for fungi Alternaria cassiae. Each fungicide were performed three experiments in completely randomized design with three repetitions and the growth was evaluated daily. Inhibition concentration (IC50;7d) of tebuconazole was $3.49 \mathrm{mg} \mathrm{L}^{-1}$, the captan was $47.36 \mathrm{mg} \mathrm{L}^{-1}$ and of mixture chlorothalonil + propamocarb hidrochloride, $64.04 \mathrm{mg} \mathrm{L}^{-1}$. Tebuconazole is classified as moderately toxic and sensitivity, captan, low toxicity and sensitivity and the mixture, non toxic and insensitive but only captan showed possibility of adverse effect for A. cassiae.
\end{abstract}

Keywords - soil, microorganism, xenobiotics, pesticide.

\section{INTRODUCTION}

The fungicides have been using control pathogenic fungi of plants and some of them are non specific and can affect the abundance of non target microorganisms (Stenersen 2004; Zhang et al., 2016). Besides, as azoles can affect the ergosterol biosynthesis, may be studied its effects for non target organisms present in the application area (Dijksterhuis et al., 2011).

As one of them, Tebuconazole is a systemic triazole classified by USEPA as carcinogenic for human beings (Konwick et al., 2006; Hu et al., 2007) and toxic for aquatic organisms ( $\mathrm{Yu}$ et al., 2013). Captan is from carboximide group, non systemic, wide range and inhibits the spores germination, growth and the oxygen uptake (Boran et al., 2012). Propamocarb is a carbamate practically non toxic and $97 \%$ is degraded by aquatic microorganisms in 35 days and chlorothalonil is a derivative of benzoic acid, considered moderately toxic and is degraded in two metabolits in two weeks (Teather et al., 2001).
The soil microbiota is responsable by decomposition of organic residues and by nutrient cycling and exercises influency in the organic matter transformation and in the carbon and mineral nutrient stocking (Zilli et al., 2003). Fungi are part of this microbiota and they are affected negatively by chemical intake according to Botelho e Monteiro (2011) who verified that inseticides, herbicides and maturers used in the manegement of sugar cane cause toxic effects for Metarhizium anisopliae and Beauveria bassiana.

Alternaria spp. is an ascomyce from Dematiaceae Family, Order Hyphomycetes and produces conidia as dictyospores (Rotem, 1994). Alternaria cassiae has wide geographic distribution in the tropical and subtropical region, as Asia (Jurair and Khan, 1960), North America (Walker and Boyette, 1982) and South America (Figueiredo et al., 1992). This fungi has a big importancy in the agroecosystem dynamic, especially, in the biological control of Senna obtusifolia (L.) (Pitelli et al., 2007) and it can be a good option as bioherbicide (Boyete et al., 2012). Besides, Alternaria is natural inhabitant of soil submited at organic or conventional manegement and for this it is exposed at pesticides (Prade et al., 2007).

Therefore, the evaluation of the pesticides effect for non target fungi is very important because the soil with unbalance fungal content can presents problems with decomposition and mineralization rate, quantity and nutrient variety, water retention capacity and erosion resistance (Stahl e Parkins, 1996).

In this context the ecotoxicology has been using as a tool to estimate the effects for non target organisms, comunities, populations, animals or vegetables, terrestrial or aquatics (Cairns e Niederlehner, 1995). According to Zagatto e Bertoletti (2008) the ecotoxicology can evaluate the damage occurred in the several ecosystems after the exposure and also to predict the future impacts of chemicals.

Thus, the risk evaluations may be more necessary to contemplate the principal agriculture patrimony, the soil 
health and fertile. The aims of this research were to estimate the toxicity of captan, tebuconazole, clorotalonil + chloridrate propamocarb and to evaluate the environmental risk for fungi Alternaria cassiae.

\section{MATERIAL AND METHODS}

\section{Cultivation of fungi}

The stain of A. cassiae was from Laboratory of Biological Control of Weed (CENARGEN/EMBRAPA), Brazil.

For the cultivation it was used the medium PDA (potatodextrose-agar) that after autoclaved at $121^{\circ} \mathrm{C}$, during 15 min, was spilled in plates and expected until solidificaton. After, it was disposed a disk from a fungi colony $(6.5 \mathrm{~mm}$ diameter) in the center of plate, from the growth active region of colony. The plates were incubated in at $25^{\circ} \mathrm{C}$ and photoperiod of 12 hours.

\section{Toxicity of fungicides for fungi}

The fungicides were captan (Captan ${ }^{\circledR}$ SC), tebuconazole (Orius ${ }^{\circledR} 250 \mathrm{EC}$ ) and the mixture clorotalonil + chloridrate propamocarb (Tattoo ${ }^{\circledR} \mathrm{C}$ ).

First of all, the sensibility of fungi was evaluated with the reference substance potassium dicromate, being IC50;7d, $65.97 \pm 9.48 \mathrm{mg} \mathrm{L}^{-1}$ (coefficient of variation 14.38\%).

Previous tests were performed and it was determinade the interval of concentrations that caused zero and $100 \%$ of inhibition in the fungi growth according IBAMA (1987), with some adaptations.

In the definitite assays the concentrations used were: captan, 1.0, 10.0, 50.0, 90.0, 130.0 and $170.0 \mathrm{mg} \mathrm{L}^{-1}$; tebuconazole, 1.0, 10.0, 20.0, 30.0, 40.0 and $50.0 \mathrm{mg} \mathrm{L}^{-1}$; and clorotalonil + chloridrate propamocarb, 25.0, 50.0, $100.0,150.0,200.0,250.0$ and $300.0 \mathrm{mg} \mathrm{L}^{-1}$ and the control. Three definitive tests were performed each one in completely randomized design with three replicates each concentration.

The fungicides were added in the medium, spilled in the plates and after solidification a disk $6.5 \mathrm{~mm}$ diameter of A. cassiae was disposed centrally. The plates were sealed and kept in the $25^{\circ} \mathrm{C}$, and photoperiod of 12 hours, for seven days.

The evaluation of growth halo was daily according two axis perpendicular. The inhibition concentration (IC50;7d) were estimated by Trimmed Spearman-Karber software (Hamilton et al., 1977).

The toxicity was classified according to Edgington et al., (1971): IC50 < $1.0 \mathrm{mg} \mathrm{L}^{-1}$ : high toxicity and sensitivity; $1.0<$ IC50 $<10.0 \mathrm{mg} \mathrm{L}^{-1}$ : moderate toxicity and sensitivity; $10.0<$ IC50 $<50.0 \mathrm{mg} \mathrm{L}^{-1}$ : low toxicity and sensitivity and IC50 > 50.0 $\mathrm{mg} \mathrm{L}^{-1}$ : non toxic and insensitive.

The environmental risk was estimated according to Urban e Cook (1986) which use the estimated environmental concentration (EEC), which is the higher and lower concentration each fungicide recommended and IC50;7d each fungicide found in the toxicity tests in vitro. Thus, these data resulte in a quotient $(\mathrm{Q})$ : without adverse effect $(\mathrm{Q} \leq 0.1)$; possibility of adverse effect $(0.1 \leq \mathrm{Q} \leq 10)$ and probability of adverse effect $(\mathrm{Q}>10)$.

\section{RESULTS}

IC50;7d of tebuconazole was $3.49 \mathrm{mg} \mathrm{L}^{-1}$; captan, 47.36 $\mathrm{mg} \mathrm{L}^{-1}$ and of mixture clorotalonil + chloridrate of propamocarb, $64.04 \mathrm{mg} \mathrm{L}^{-1}$ (Table 1) and they were classified as moderately toxicity and sensitivity; low toxicity and sensibility and non toxic and insensitive, respectively.

Table.1: Inhibition Concentration 50\% (IC50;7d) (mg $\mathrm{L}^{-}$ $\left.{ }^{1}\right)$, upper limit $(U L)$ and lower limit ( $\left.L L\right)$ of fungicides for A. cassiae.

\begin{tabular}{cccc}
\hline \multicolumn{3}{c}{ Captan } \\
\hline Tests & LL & IC50;7d & UL \\
\hline $\mathbf{1}$ & 48.44 & 60.00 & 74.57 \\
$\mathbf{2}$ & 37.81 & 44.98 & 53.53 \\
$\mathbf{3}$ & 25.99 & 37.00 & 52.79 \\
Average & $\mathbf{3 7 . 4 1}$ & $\mathbf{4 7 . 3 6}$ & $\mathbf{6 0 . 2 9}$ \\
\hline \multicolumn{4}{c}{ Tebuconazole } \\
\hline Tests & LL & IC50;7d & UL \\
\hline $\mathbf{1}$ & 2.95 & 3.98 & 5.38 \\
$\mathbf{2}$ & 2.95 & 4.14 & 5.81 \\
$\mathbf{3}$ & 1.33 & 2.37 & 4.23 \\
Average & $\mathbf{2 . 4 1}$ & $\mathbf{3 . 4 9}$ & $\mathbf{5 . 1 4}$ \\
\hline \multicolumn{4}{c}{ Clorotalonil + Chloridrate de Propamocarb } \\
\hline Tests & LI & CE50;7d & LS \\
\hline $\mathbf{1}$ & 51.06 & 66.73 & 87.22 \\
$\mathbf{2}$ & 52.58 & 80.04 & 121.84 \\
$\mathbf{3}$ & 30.59 & 45.37 & 67.32 \\
Average & $\mathbf{4 4 . 7 4}$ & $\mathbf{6 4 . 0 4}$ & $\mathbf{9 2 . 1 2}$ \\
\hline LL: lower limit; UL: upper limite; IC50 - inhibition \\
\multicolumn{4}{c}{ concentration 50\% } \\
Capt
\end{tabular}

Captan caused $8 \%$ of inhibition with $1.0 \mathrm{mg} \mathrm{L}^{-1}$ and $81 \%$ with $170.0 \mathrm{mg} \mathrm{L}^{-1}$. Tebuconazole caused $26 \%$ with 1.0 $\mathrm{mg} \mathrm{L}^{-1}$ and $83 \%$ with $50.0 \mathrm{mg} \mathrm{L}^{-1}$, but there was a stabilization trend from $20.0 \mathrm{mg} \mathrm{L}^{-1}$. Mixture, caused 36\% with $25.0 \mathrm{mg} \mathrm{L}^{-1}$ and $73 \%, 300.0 \mathrm{mg} \mathrm{L}^{-1}$ (Figure 1). 

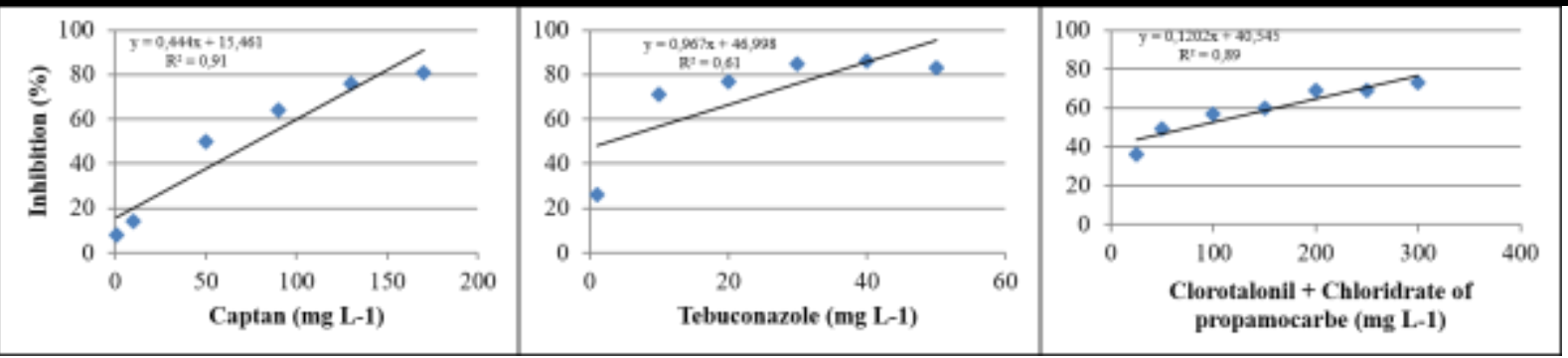

Fig.1: Relation of concentration effect of fungicides for Alternaria cassiae.

In relation to environmental risk, captan has possibility of adverse effect, therefore tebuconazole and the mixture don't cause any adverse effect for fungo $A$. cassiae, independent of the dosage, according to Urban and Cook (1986) (Table 2).

Table.2: Environmental risk of fungicide for Alternaria cassiae.

\begin{tabular}{lccc}
\hline Fungicides & EEC $\left(\mathbf{m g ~ m}^{-2}\right)$ & Q=EEC/IC50 & Classification \\
\hline \multirow{2}{*}{ Captan } & 12.00 & 0.25 & PAE \\
& 16.80 & 0.35 & PAE \\
Tebuconazole & 0.075 & 0.02 & AAE \\
\hline \multirow{2}{*}{ Chlorothalonil + Chloridrate Propamocarb } & 0.150 & 0.04 & AAE \\
& 1.80 & 0.03 & AAE \\
\hline
\end{tabular}

ECC: estimate environmental concentration; PAE: possibility adverse effect $(0.1 \leq \mathrm{Q} \leq 10)$; AAE: any adverse effect $(\mathrm{Q} \leq 0.1)$

\section{DISCUSSION}

The influence of fungicides for soil microorganisms depends of many factors between the physical properties, biochemical soil and fungicide concentration (Vyas, 1988). Fungicide effects for microorganisms envolve modification of availability and transformation of nytrogen, as nitrification and desnitrification (Chen et al., 2001) and consequentely in the soil quality. Then, the soil quality affects your potential, productivity and global sustainable of the agroecosystem and become necessary your study to secure the decisions for the better use of this resource (Sposito and Zabel, 2003).

Tebuconazole was the more toxic for $A$. cassiae $(3,49 \mathrm{mg}$ $\mathrm{L}^{-1}$ ) and its toxicity is associated with inhibition of ergosterol synthesis, one component of fungal membrane and responsable by fluidity regulation, activity and distribution of integral proteins and control of celular cycle (Bard et al., 1993). This characterize the ergosterol biosynthesis way as essential for fungal growth (AlcazarFuoli et al., 2008). Tebuconazole also was toxic with low concentrations for Colletotrichum gloeosporioides, IC50 $<1.0 \mathrm{mg} \mathrm{L}^{-1}$, which causes diseases in papaya (Tavares and Souza, 2005) and it showed high patogenecity in vitro for Lasiodiplodia theobromae, IC50 of $0.42 \mathrm{mg} \mathrm{L}^{-1}$ (Locatelli et al., 2015).

Captan offers risk for $A$. cassiae and it can unbalance the fungal content in the soil. Others agrochemicals used in the sugar cane (insecticides aldicarbe and fipronil, herbicides diuron and clomazone+ametryn and maturers etil-trinexapac and sulfometurom-metilic) were toxic for fungi Metarhizium anisopliae and Beauveria bassiana afecting the biological control by these fungi (Botelho and Monteiro, 2011).

Tebuconazole was more toxic that others but it doesn't cause risk for this funghi because the EEC is much lower that IC50. According Carraschi et al (2015), the closer the recommended dose of the insecticide thiameothoxan is from the lethal concentration, the greater the possibility of it causing an adverse effect for a bioindicator. This relation also was verified with capatan and the mixture for A. cassiae.

Beside the fungi, the bacterial biomas also can be affected by agrochemicals use. According Widenfalk et al. (2008) captan doesn't cause negative effects in the microbial biomass using the dosage permited and according to Milenkovski et al. (2010) only was observed some effect when used larger doses than found in the environment. Tebuconazole decrease the bacterial biomass in the litter after chronic exposure (six weeks, $20.0 \mu \mathrm{g} \mathrm{L}^{-1}$ ) (Artigas et al., 2012). About clorotalonil, Xiaoqiang et al. (2008) described that the inhibitory effect by clorpirifós for soil organisms is increased when it is associated with clorotalonil. 


\section{CONCLUSION}

Tebuconazole causes moderately toxicity, captan, low toxicity and the mixture is considered non toxic for $A$. cassiae, the funghi non target, but only captan represents the possibility of adverse effect for this organism.

\section{ACKNOWLEDGMENTS}

At CNPq process MS/CNPq 131410/2006-7.

\section{REFERENCES}

[1] Alcazar-Fuoli, L., Mellado, E., Garcia-Effron, G., Lopez, J. F., Grimalt, J.O., Cuenca-Estrella, J.M. and Rodriguez-Tudela, J.L. 2008. Ergosterol biosynthesis pathway in Aspergillus fumigatus. Steroids. 73(3): 339-347.

[2] Artigas, J., Majerholc, J., Foulquier, A., Margoum, C., Volat, B., Neyra, M. and Pesce, S. 2012. Effects of the fungicide tebuconazole on microbial capacities for litter breakdown in streams. Aqu Toxicol. 122: 197-205.

[3] Bard, M., Lees, N.D., Turi, T., Craft, D., Cofrin, L., Barbuch, R., Koegel, C. and Loper, J.C. 1993. Sterol synthesis and viability of erg11 (cytochrome P450 lanosterol demethylase) mutations in Saccharomyces cerevisiae and Candida albicans. Lipids. 28: 963967.

[4] Boran, H., Capkin, E., Altinok, I. and Terzi, E. 2012. Assessment of acute toxicity and histopathology of the fungicide captan in rainbow trout. Experim Toxicol Path. 64(3): 175-179.

[5] Botelho A.A.A., Monteiro, A.C. 2011. Toxicidade de agrotóxicos usados no cultivo da cana-de-açúcar para fungos entomopatogênicos no solo. Pesticidas: Rev Ecotoxicol e Meio Ambi. 21: 73-84.

[6] Boyette C.D., Bryson, C.T., Hoagland, R.E. and Weaver, M.A. 2012. Effects of simulated rainfall on disease development and weed control of the bioherbicidal fungi Alternaria cassiae and Colletotrichum truncatum. Weed Technol. 26(1): 117-121.

[7] Cairns, J.Jr. and Niederlehner, B.R. 1995. Ecological Toxicity Testing. Lewis Publishers, Boca Raton, USA, pp. 240.

[8] Carraschi S.P., Florencio, T., Garlich, N., Silva, A. F., Marques, A.M., Cruz, C. and Ranzani-Paiva, M.J.T. 2015. Ecotoxicology of drugs used in fish disease treatment. J Environ Chem Ecotoxicol. 7(3): 31-36.

[9] Chen, S.K., Edwards, C.A. and Subler, S. 2011. Effects of the fungicides benomyl, captan and chlorothalonil on soil microbial activity and nitrogen dynamics in laboratory incubations. Soil Biol Bioch. 33(14): 1971-1980.
[10] Dijksterhuis, J., van Doorn, T., Samson, R. and Postma, J. 2011. Effects of seven fungicides on nontarget aquatic fungi. Water, Air, Soil Poll. 222(1-4,): 421-425.

[11] Edgington, L.V., Khew, K.L. and Barron, G.L. 1971. Fungitoxic spectrum of benzimidazoles compounds, Phytopathol. 61: 42-44.

[12] Figueiredo, G., Fontes, E.G., Teixeira, C.A.B. and Pais, J.S. 1992. Levantamento e seleção de patógenos para controle biológico de fedegoso (Senna obtusifolia). Fitopatol Brasil. 17: 169.

[13] Hamilton, M.A., Russo, R.C. and Thurston, R.V. 1977. Trimmed Spearman-Karber method for estimating medial lethal concentrations in toxicity bioassays. Environ Sci Technol. 7: 714-719.

[14] Hu, M.L., Jiang, M., Wang, P., Mei, S.R., Lin, Y.F., Hu, X.Z., Shi, Y., Lu, B. and Dai, K. 2007. Selective solid-phase extraction of tebuconazole in biological and environmental samples using molecularly imprinted polymers. Analyt Bioanaly Chem. 387(3): 1007-1016.

[15] IBAMA. Instituto Brasileiro do Meio Ambiente e dos Recursos Naturais Renováveis. 1987. Avaliação da toxicidade aguda para peixes. Parte D. 3. Manual de testes para avaliação de ecotoxicidade de agentes químicos. Brasília, DF, pp. 23.

[16] Jurair, A.M.N. and Khan, A.A. 1960. New epecies of Alternaria on Cassia holsericea. Fresem. Pak J Scient Industr Res. 3: 71-72.

[17] Konwick, B.J., Garrison, A.W., Avants, J.K., Fisk, A.T. 2006. Bioaccumulation and biotransformation of chiral triazole fungicides in rainbow trout (Oncorhynchus mykiss). Aquat Toxicol. 80(4): 372381.

[18]Locatelli, T., Freire, M.D.G.M., de Souza, C.L.M. and Dias, V.M. 2015. Toxicidade de fungicidas no crescimento e germinação in vitro do fungo Lasiodiplodia theobromae. Biol \& Saúde. 5(17);. 922.

[19] Milenkovski, S., Bååth, E., Lindgren, P.E. and Berglund, O. 2010. Toxicity of fungicides to natural bacterial communities in wetland water and sediment measured using leucine incorporation and potential denitrification. Ecotoxicol. 19(2): 285-294.

[20] Pitelli, R.L.C.M., Penariol, M., Pitelli, A.M.C.M. and Pitelli, R.A. 2007. Host specificity of a brazilian isolate of Alternaria cassiae (Cenargen CG593) under greenhouse conditions. Phytoparasit. 35(2):123-128.

[21] Prade, C.A., Matsumura, A.T., Ott, A.P. and Porto, M.L. 2007. Diversidade de fungos do solo em sistemas agroflorestais de citrus com diferentes tipos 
de manejo no município de Roca Sales, Rio Grande do Sul, Brasil. Bioci. 15(1): 73-81.

[22] Rotem, J. 1994. The Genus Alternaria: Biology, Epidemiology and Pathogenicity. St. Paul, Minnesota, pp. 326.

[23] Sposito, G. and Zabel, A. 2003. The assessment of soil quality. Geoderma. 114: 143-144.

[24] Stahl, P.D. and Parkins, T.B. 1996. Relationship of soil ergosterol concentration and fungal biomass. Soil Biol Biochem. 28: 847-855.

[25] Stenersen, J. 2004. Chemical pesticides mode of action and toxicology. CRC press. pp. 296.

[26] Tavares, G.M. and Souza, P.E.D. 2005. Efeito de fungicidas no controle in vitro de Colletotrichum gloeosporioides, agente etiológico da antracnose do mamoeiro (Carica papaya L.). Ciênci Agrotecnol. 29(1): 52-59, 2005.

[27] Teather, K., Harris, M., Boswell, J. and Gray, M. 2001. Effects of Acrobat MZ® and Tattoo ${ }^{\circledR}$ on Japanese medaka (Oryzias latipes) development and adult male behavior. Aqu Toxicol. 51(4): 419-430.

[28] Urban, D.J. and Cook, N.J. 1986. Hazard evaluation division - Standard evaluation procedure ecological risk assessment. Washington, USEPA Publication 540/9-86-001, pp. 96.

[29] Vyas, S.C. 1988. Soil microorganisms and their activities. In: Vyas, S. C. (Ed.) Non-target effects of agricultural tebuconazoles. Boca Raton: CRC Press, p. 131-160.

[30] Walker, H.L. and Boyette, C.D. 1986. Biocontrol of sicklepod (Cassia obtusifolia) in soybeans (Glycine max) whit Alternaria cassiae. Weed Sci. 33: 212215.

[31] Widenfalk, A., Bertilsson, S., Sundh, I. and Goedkoop, W. 2008. Effects of pesticides on community composition and activity of sediment microbes-responses at various levels of microbial community organization. Environ Pollu. 152(3): 576-584.

[32] Xiaoqiang, C.H.U., Hua, F.A.N.G., Xuedong, P.A.N., Xiao, W.A.N.G., Min, S.H.A.N., Bo, F.E.N.G. and Yunlong, Y.U. 2008. Degradation of chlorpyrifos alone and in combination with chlorothalonil and their effects on soil microbial populations. J Environ Sci. 20(4): 464-469.

[33] Yu, L., Chen, M., Liu, Y., Gui, W. and Zhu, G. 2013. Thyroid endocrine disruption in zebrafish larvae following exposure to hexaconazole and tebuconazole. Aqua Toxicol. 138: 35-42.

[34]Zagatto, P.A. and Bertoletti, E. 2008. Ecotoxicologia aquática - princípios e aplicações. São Carlos: RIMA, pp. 478.
[35]Zhang, M., Xu, Z., Teng, Y., Christie, P., Wang, J., Ren, W., Luo, Y. and Li, Z. 2016. Non-target effects of repeated chlorothalonil application on soil nitrogen cycling: the key functional gene study. Sci Total Environ. 543: 636-643.

[36]Zilli, J.É., Rumjanek, N.G., Xavier, G.R., Costa Coutinho, H. L. and Neves, M.C.P. 2003. Diversidade microbiana como indicador de qualidade do solo. Cadernos de Ciênci Tecnol. 20(3): 391-411. 